\title{
RESEARCH SUMMARY \\ MODELS AND STRATEGIES FOR DEVELOPING THE ELECTRICITY SECTOR IN INDONESIA AS A KEY ELEMENT FOR POVERTY ERADICATION: Evaluation of The First Year
}

\author{
MAXENSIUS TRI SAMBODO, SIWAGE DHARMA NEGARA, AHMAD HELMY FUADY AND \\ INNE DWI ASTUT1 ${ }^{1}$
}

\begin{abstract}
This study is part of multiyear research on electricity access at remote areas. The end goal of the study is to develop a model of electricity access in remote area. We collected a baseline information as part of quasi experimental study at some villages, in Satar Mese sub-district, East Nusa Tenggara. The baseline data showed three major finding. First, households with electricity access spent significantly less on kerosene. Second, access to electricity increases spending on non-food items significantly. Third, because the off grid SEHEN program is for lighting, we do not obtain strong evidence for a causal relation between electricity access and increases in working hours. We found that access to electricity can improve peoples welfare through increasing spending on food and non-food spending. This mechanism can work because the price of SEHEN is relatively cheaper than kerosene light. Thus, people obtained extra saving on energy spending. In the long terms, we expect, more jobs can be created when electricity production increases.
\end{abstract}

Keyword: Electricity access, remote areas, welfare.

\begin{abstract}
Abstrak
Studi ini merupakan bagian dari penelitian jangka panjang terkait akses listrik bagi wilayah terpencil. Tujuan akhir dari studi ini yaitu untuk membangun atau mengembangkan model akses listrik di daerah terpencil. Data awal telah dikumpulkan sebagai bagian dari studi quasi experiment di beberapa desa di kecamatan Satar Mese, Nusa Tenggara Timur. Analisis data awal menunjukkan tiga temuan penting. Pertama, rumah tangga dengan akses listrik memiliki tingkat konsumsi minyak tanah yang lebih rendah dibandingkan dengan yang tidak memiliki listrik. Kedua, ada indikasi akses listrik telah mendorong naiknya belanja non makanan. Ketiga, karena akses listrik off grid SEHEN hanya untuk penerangan, maka belum terlihat dampak yang nyata terhadap peningkatan waktu bekerja. Studi ini menunjukkan akses listrik dapat meningkatkan kesejahteraan masyarakat melalui peningkatan belanja makan dan non makan. Hal ini dapat terjadi karena secara relatif belanja energi makin rendah dengan adanya akses listrik. Sebagaian belanja energi dapat ditabung oleh masyarakat untuk kebutuhan lainya. Dalam jangka panjang, dengan semakin tingginya produksi listrik, diharapkan potensi kesempatan kerja dapat lebih banyak tercipta.
\end{abstract}

Kata kunci: akses listrik, daerah terpencil, kesejahteraan.

I Maxensius Tri Sambodo, Siwage Dharma Negara, and Inne Dwi Astuti are researchers from Economic Research Center and Ahmad Helmy Fuady is a researcher from Research Center for Regional Resources. All researchers are from Indonesian Institute of Sciences (LIPI). Authors can be contacted at maxsooi@lipi.go.id or samxensius@yahoo.com.

This summary is drawn from the research report titled, Model dan Strategi Pengembangan Sektor Ketenagalistrikan di Daerah Dalam Upaya Pengentasan Kemiskinan. This research was funded by the Indonesian Institute of Sciences (LIPI) under the competitive research program for the period 2013 - 2015. This current study is organised by the Critical and Strategic Social Issues (CSSI) sub-program.

Copyright (20I6 The Author, (20I6 Deputy of Social Sciences and Humanities. All rights reserved. Printed in Indonesia. Journal of Indonesian Social Sciences and Humanities (JISSH); Vol. 6, Issue 2, (2016), Pp. 65-70. ISSN: 1979-843I. 


\section{INTRODUCTION}

Energy poverty has become a global challenge. In September 20II, the United Nations General Assembly launched the 'Sustainable Energy for All' initiative. It has three objectives that are to be pursued until 2030: ensuring universal energy access; doubling the proportion of renewable energy; and doubling the efficiency of energy production over the period 2015 to $2030 .^{2}$ This indicates that, by 2030, it is hoped that all people in the world will have access to modern energy services for cooking and other domestic uses. Indonesia as a member of the global community has a responsibility to support the program and to ensure that sustainable energy is available for all its development programs.

Energy is one dimension of poverty. The global Multidimensional Poverty Index also indicates that lack of access to modern supplies of energy has become an important factor in explaining the causes of poverty among the ASEAN countries. For example; in Cambodia, inadequate supplies of electricity and cooking fuel as causes of poverty are of the highest rank; in Laos, Indonesia and Vietnam, they are the second highest; and in Thailand and the Philippines, they are the third highest (after years of schooling and mortality rates). This indicates that universal access to energy can help the poor.

Table I Percentage contribution of deprivation of each dimension to overall poverty

\begin{tabular}{|c|c|c|c|c|c|c|}
\hline & $\begin{array}{l}\text { Thai- } \\
\text { land }\end{array}$ & $\begin{array}{l}\text { Viet- } \\
\text { nam }\end{array}$ & $\begin{array}{l}\text { Philip- } \\
\text { pines }\end{array}$ & $\begin{array}{l}\text { Indo- } \\
\text { nesia }\end{array}$ & $\begin{array}{l}\text { Lao } \\
\text { PDR }\end{array}$ & $\begin{array}{l}\text { Cambo- } \\
\text { dia }\end{array}$ \\
\hline $\begin{array}{l}\text { Years of } \\
\text { schooling }\end{array}$ & 29.2 & 18.5 & 15.8 & 6.2 & 16 & 14 \\
\hline $\begin{array}{l}\text { Child school } \\
\text { attendance }\end{array}$ & 11.5 & 14.3 & - & 6.4 & 15.4 & 8.1 \\
\hline $\begin{array}{l}\text { Mortality } \\
\text { (any age) }\end{array}$ & 19 & 12.9 & 56.5 & 60.7 & 18.9 & 13.5 \\
\hline Nutrition & 12.2 & 12.2 & - & - & 11.5 & 19.3 \\
\hline Electricity & 1.2 & 1.5 & 3.8 & 1.5 & 6.3 & 10.9 \\
\hline $\begin{array}{l}\text { Improved } \\
\text { sanitation }\end{array}$ & 4.8 & 12.1 & 5.3 & 6.7 & 9 & 10.6 \\
\hline $\begin{array}{l}\text { Drinking } \\
\text { water }\end{array}$ & 4.4 & 5.5 & 2.5 & 5.1 & 5.3 & 6.8 \\
\hline Flooring & 2.5 & 5.5 & 1.5 & 1.9 & 2.3 & 1 \\
\hline Cooking fuel & 10.6 & 13.1 & 9.6 & 8 & 10.9 & 11.9 \\
\hline $\begin{array}{l}\text { Asset owner- } \\
\text { ship }\end{array}$ & 4.6 & 4.4 & 4.9 & 3.5 & 4.4 & 4 \\
\hline
\end{tabular}

2 See http://www.se4all.org/wp-content/uploads/2014/oi/SEFA-Action-Agenda-Final.pdf, accessed I8 June 2014
The number of people, in 20II, without access to electricity in Indonesia was about 66 million, the highest among the ASEAN countries and the electrification ratio was still about 73 per cent, the lowest rate compared to the rates of the original members of ASEAN (see Table 2). At that time the rural electrification rate for Indonesia was also relatively low at 60 per cent. It is important to note that the electrification ratio varies across the provinces and islands; for example, in Java the ratio was about 78 per cent, but in Nusa Tenggara Timur (NTT) province, it was about 46.5 per cent (PLN, 20I2). A low electrification ratio also means low electricity consumption per capita. According to PLN (2012), electricity consumption per capita in NTT was about II $\mathrm{kWh}$, that is, lower than the national average, which was 712 $\mathrm{kWh}$ per capita (PLN, 2012). Thus, based on the above information, we can conclude that, Java apart, country-wide electricity distribution is a major challenge and this affects the performance of the power sector nationally and regionally.

Table 2 Electricity access $201 \mathrm{I}$

\begin{tabular}{lllll}
\hline Country & $\begin{array}{l}\text { Population } \\
\text { without } \\
\text { electricity } \\
\text { (millions) }\end{array}$ & $\begin{array}{l}\text { Electri- } \\
\text { fication } \\
\text { rate } \\
(\%)\end{array}$ & $\begin{array}{l}\text { Urban elec- } \\
\text { trification } \\
\text { rate } \\
(\%)\end{array}$ & $\begin{array}{l}\text { Rural elec- } \\
\text { trification } \\
\text { rate } \\
(\%)\end{array}$ \\
\hline $\begin{array}{l}\text { Brunei } \\
\text { Darussalam }\end{array}$ & 100 & 100 & 99 \\
\hline Cambodia & 9 & 34 & 97 & 18 \\
\hline Indonesia & 66 & 73 & 85 & 60 \\
\hline Laos & 1 & 78 & 93 & 70 \\
\hline Malaysia & 0 & 100 & 100 & 99 \\
\hline Myanmar & 25 & 49 & 89 & 29 \\
\hline Philippines 28 & 70 & 89 & 52 \\
\hline Singapore & 0 & 100 & 100 & 100 \\
\hline Thailand & 1 & 99 & 100 & 99 \\
\hline Vietnam & 4 & 96 & 100 & 94 \\
\hline Source: & IEA, World development outlook, 20I3
\end{tabular}

After investigating the causes of inadequate access to electricity, especially in rural areas, this study investigates the distribution of electricity in Satar Mese sub-district, Manggarai District, and in NTT Province. There are three main reasons why we selected Satar Mese for our research. First, the Ulumbu geothermal power plant, which has been in operation since 20II in Satar Mese, has a capacity of $2 \times 2.5$ MW. According to the government's estimate, Ulumbu has the potential to produce about $200 \mathrm{MW} .{ }^{3}$ Currently, Ulumbu supplies electricity

3 See http://www.esdm.go.id/berita/45-panasbumi/ 3640-potensi-panas-bumi-ntt-mencapai-I266-mw.html, accessed 9 July 2014. 
for Ruteng's system. Second, Ulumbu is in Satar Mese and according to information from the Mining and Energy Agency, at the district level, about 16 villages or 70 per cent of all villages in Satar Mese do not have a supply of electricity. Thus, the Ulumbu power plant has not benefited the nearby villages. Third, from information from the PLN office at Ruteng (a city in Manggarai District), we learnt that Kampong Tantong in Wewo village will be connected to electricity in $2013 .{ }^{4}$ Thus, we selected Kampong Tantong as a treatment group and other kampongs, such as Lungar-Mesir and Damu, as a control group (see Table 3). ${ }^{5}$ Thus, the Ulumbu power plant and the villages nearby provide the perfect case for the research team to investigate the economic, social, and political dimensions of rural electrification programs in Indonesia. Further, Ulumbu can provide a deep insight on the role of renewable energy for promoting rural electrification programs.

Table 3 Baseline data in 2013

\begin{tabular}{lll}
\hline & Village & Note \\
\hline 1 & $\begin{array}{l}\text { Kampong } \\
\text { Tantong }\end{array}$ & $\begin{array}{l}\text { We surveyed } 60 \text { households and for } \\
\text { lighting, } 24 \text { households use electricity and } \\
\text { kerosene and the rest use kerosene only. }\end{array}$ \\
\hline 2 & $\begin{array}{l}\text { Kampong } \\
\text { Lungar- } \\
\text { Mesir }\end{array}$ & $\begin{array}{l}\text { There are } 205 \text { households and of those } 75 \\
\text { do not have access to electricity. }\end{array}$ \\
\hline 3 & Kampong \\
Damu & $\begin{array}{l}\text { There are } 46 \text { households; about } 28 \text { use } \\
\text { electricity and kerosene, and, of those } 28 \\
\text { households, } 8 \text { use a metered electricity } \\
\text { supply. }\end{array}$ \\
\end{tabular}

Source: Primary data

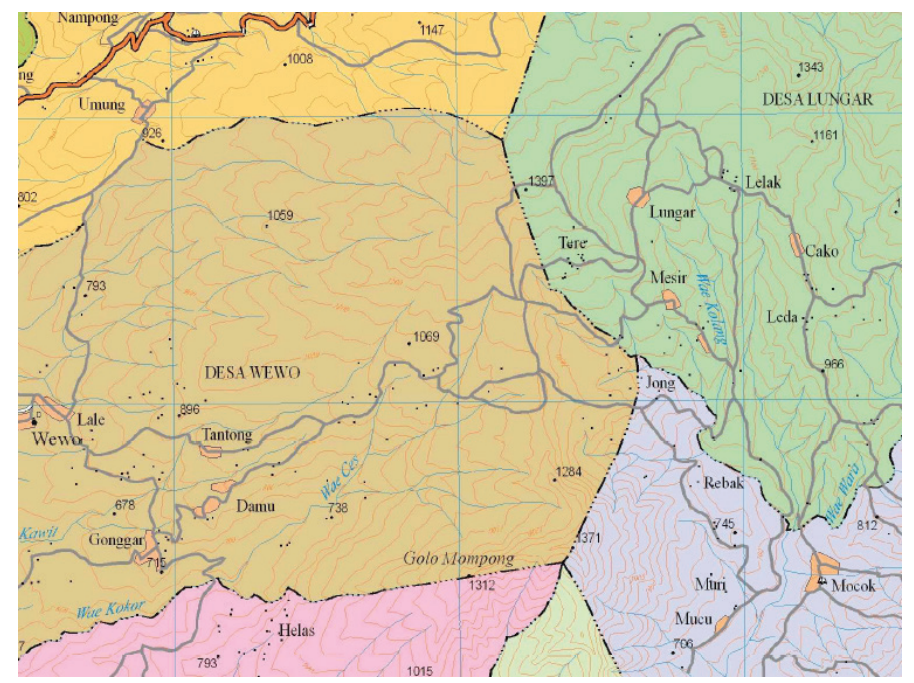

Figure I Location of primary data survey

$4 \quad$ In March 20I4, Kampong Tantong was connected to electricity supplied by the Ulumbu power plant.

5 Treatment and control groups indicate that we attempt to measure the effect of electricity access on people's welfare. In the first year of this study (2013), we collected the baseline data and in 2014 we conducted the second survey to capture the effect of the improvement in the distribution of electricity.
We argue that improving electricity access is an important step in alleviating poverty. It is necessary to understand the process, to investigate conditions, and to analyse organisational and institutional arrangements. All these elements are important for designing models and strategies that can create conditions for a more sustainable electricity supply. We organise the summary of this research report into five sections. After an introduction, we review briefly the literature on electricity supply and poverty alleviation. Section three reviews the current conditions of organisational and institutional dimensions. Then we summarise major findings on electricity access and people's welfare from primary and from secondary data sources. Finally, we discuss the implications for policy.

\section{LITERATURE REVIEW}

Increasing the ratio of electrification (that is, the proportion of the population that has an electric power supply) has important implications for efforts to achieve the Millennium Development Goals (UNDP, 2005). Studies indicate that electricity access can improve people's welfare (Reiche et al., 2000; Peng and Pan, 2006; and Al Mohtad, 2006). Reiche et al. (2000) argue that electricity access can improve the standard of living (amenities and public services), reduce the use of conventional energy sources (such as firewood), which in turn can increase environmental health and quality, increase job opportunities (direct and indirect effects of electrification programs), and improve productivity. Similarly, Kanagawa and Nakata (2008) show that energy access can improve health, education, income and the environment. Barnes (I988), investigating the effect of electrification ratios on women in rural India, found that electricity access reduces the time spent searching for firewood and that that time saved can be devoted to reading and other activities that can increase income. Access to electricity can also improve health conditions: when people shift from using kerosene to electricity for lighting, air quality in the immediate environment improves significantly. As well, electric lamps also reduce fire risks and electricity can enable better access 
to information and to telecommunication technology, such as mobile phones, radio, television, and the internet.

In Indonesia, rural electrification programs have been implemented since the I950s; small diesel power plants have been installed in many villages and in remote areas. McCawley (I978) says that rural electrification programs are to improve productivity in agricultural sectors and to improve rural industries. In I984, about 25 per cent of a total of 65,700 villages had access to electricity (Munasinghe, I988). Currently, the rural electrification ratio for Indonesia is about 87 per cent. For some provinces, such as DKI Jakarta, Jawa Tengah, DI Yogyakarta, Sulawesi Utara, Sulawesi Selatan, and Nusa Tenggara Barat, the ratio has reached ioo per cent. According to the long-term development plan (20IO-I4), the Indonesian government is attempting to reach an electrification ratio of about 80 per cent and a rural electrification ratio of 98.9 per cent.

However, implementing rural electrification programs has many problems. McCawley (I978) considers there are six categories of problems for rural electrification programs: technical difficulties; quality of services; administration; inadequate demand; high costs; and program financing. It is important to note that all the problems are connected. Technical problems are related to the ability to conduct operations and maintenance. Lack of skills and knowledge to maintain and repair equipment, and shortage of spare parts, have caused programs to be foreshortened. Because of the lack of knowledge and skills to maintain the plants, the quality of service has become poor. Administrative skills to manage the program are inadequate and not well supported by the senior management of the relevant governing institutions. Because rural communities mostly use electricity for lighting, demand is relatively low. From a social welfare perspective, the benefits are substantial; however, from a business point of view, the investment conditions might not be favourable because the returns are over the long term. If the funding for the program is insufficient, this will lead to lower revenue, which means that operating costs cannot be met easily.
Electricity supply needs to be of reliable quality and sufficient for needs. AGECC (2010) indicates that electricity use gradually increases from basic needs to effective use and finally to support a modern lifestyle. Electricity consumption will increase from 50 to Ioo $\mathrm{kWh}$ per capita per year to about $2000 \mathrm{kWh}$ per capita per year (AGECC, 20Io). As a result, investment in power supply needs to be increased to ensure that people have enough electricity to sustain their commercial and social activities.

\section{ORGANISATIONAL AND INSTITUTIONAL DIMENSIONS}

According to article 3, law 30 of 2007 (on energy), access to energy, especially for the poor and in remote areas, is necessary to improve welfare and to improve equity. The government needs to provide assistance for poor people and to promote energy infrastructures to reduce disparities across the regions. Improving energy access is not only a responsibility of central government but also of local government. According to article 3, law 30 of 2007 (on energy), power can be supplied by central and by local government under the decentralisation principles.

We argue that, although the electricity law has clearly explained in detail the roles of central and local government (provincial, district or city), local governments still remain dissatisfied with the current law. For example, articles io and II indicate that businesses in the electricity sector, such as those generating, transmitting, distributing and selling power may operate as one business entity and in one business area. The business entity may be owned by a stateowned company, a local government company, a cooperative, a community or the private sector, but priority to conduct the business needs to be given to state-owned enterprises. This condition allows PLN (the state electricity company) to monopolise the market, which is contrary to the principle of decentralisation. We also point out that, for practical purposes, local government has neither the capacity nor capability to participate in the electricity business. In Manggarai District, we have not found any local regulation for electricity and the local government is struggling to find ways to participate in electricity business. 
We note that the local government is aware that the Ulumbu power plant provides substantial benefits for its people. However, local government expects direct benefits from Ulumbu for the local budget. Local government notes that Ulumbu has reduced consumption of high-speed diesel fuel and PLN obtains significant benefits from this. However, the more substantial reason is that the local government has not obtained royalties or revenue sharing from PLN. As a result, the local government is always questioning the legal aspects of geothermal power plants, especially in relation to permits for mining activities (izin usaha pertambangan). We argue that central and local governments and PLN need to develop mutual understanding and to formulate win-win solutions. It is also necessary to develop a framework to enable local governments to actively participate in improving the electrification ratio.

Further, we highlight organisational problems in implementation. There are many agencies involved in rural electrification programs. They focus on promoting solar panel systems, on centralised and on individual programs, such as SEHEN (funded by PLN) and SHS (funded by the central government through its ministries, such energy and mineral resources). The programs have different characteristics but they are competing one with the others; we have termed them 'predatory' programs and to some extent this makes for confusion. For example, the SEHEN program requires monthly payments but SHS is provided free. SEHEN has a capacity of about 12 Watt power (Wp) but the capacity of SHS is greater than I2 Wp. Thus, it is necessary to develop program synergies and standards. We argue that the current system, in promoting electricity access through solar panels, will not be sustainable unless there are agencies or institutions responsible for after sales service and for training local communities to improve their capability to maintain the programs.

\section{ELECTRICITY AND PEOPLE'S WEL- FARE IN RURAL AREAS}

We briefly describe the background of our research area. In 20II, the total population in
Satar Mese sub-district was about 33,000 or about II per cent of the population of Manggarai District. The area of Satar Mese sub-district is about 300 square kilometres and has a population density about iıo people per square kilometre; the number of households (in 20II) was about 7000 (BPS, 20I2). Most of the people in Satar Mese work in the agricultural sector to produce paddy, coconuts, coffee, candleberry nuts, cloves and cashew nuts; some also make moke or sofie (traditional alcoholic drinks); and some women also weave. The number of poor people in Satar Mese is relatively high: according to data from the National Team for the Acceleration of Poverty Reduction ( $\mathrm{TNP}_{2} \mathrm{~K}$ ), 20,000 or 60 per cent of the population of Satar Mese are poor and more than half the households (about 3600) are poor.

A high rate of poverty has consequences for several social indicators. Most children under 15 years old need to work to help their parents and this can affect the quality of their education. Further, this also affects their capacity to continue their education to a higher standard. We also indicate that in many villages most parents need to send their children to the nearby city to complete their education, even for junior high school. We also indicate that availability of infrastructure, such as roads and electricity, still need to be improved. Data from $\mathrm{TNP}_{2} \mathrm{~K}$ indicates that about 500 households or only about 7 per cent of the households in Satar Mese have access to electricity from PLN.

We used two strategies in evaluating the effect of electricity access on people's welfare. First, we used the National Socioeconomic Survey (SUSENAS) for core data for July 2009 and July 20Io. We separately analysed data for the two periods. Second, we used the baseline data from the three villages near the Ulumbu power plant (see Table 3).

There are four major findings from SUSENAS data. First, households with electricity access have higher expenditure on health and education compared to households without. Second, we found electricity access can increase household health spending by 9.8 per cent (ceteris paribus) and education spending by $\mathrm{I} 4$ per cent (ceteris paribus). Third, the analysis 
also indicates that electricity access reduces food spending by 4.6 per cent (ceteris paribus) but increases expenditure for non-food items. The results are consistent using SUSENAS data for 2009 and for 20Io. Finally, the study also indicates that family characteristics, such as number of family members, income, location (urban or rural), access to clean water, and land area, are determinants of household expenditure.

The analysis from the baseline data produced three major findings. First, households with electricity access spent significantly less on kerosene. We have four pieces of evidence to support this argument: (I) households with no access to electricity have a higher proportion of expenditure on kerosene than do households with electricity access and the difference is statistically significant; (2) access to electricity reduces spending on kerosene by 3I per cent (ceteris paribus); (3) villages with no electricity access spend 24 per cent more on kerosene than those with access to a supply of electricity (ceteris paribus); and (4) the SEHEN program can reduce spending on kerosene by 52.5 per cent (ceteris paribus).

Second, access to electricity increases spending on non-food items significantly, by 38 per cent (ceteris paribus). In the case of SEHEN, we found that electricity access can increase spending for food by $\mathrm{I} 6$ per cent (ceteris paribus) and non-food by 34 per cent (ceteris paribus). Third, because the SEHEN program is for lighting, we do not obtain strong evidence for a causal relation between electricity access and increases in working hours.

In conclusion we argue that access to electricity can improve people's welfare through two main channels; food and non-food spending. The analysis from the baseline data shows that this happened because spending was reallocated from kerosene to other spending and this reallocation indicates that the relative price of electricity is less than that of kerosene.

\section{CONCLUSION}

The government should improve electricity connectivity for the eastern part of Indonesia. Support is needed for poor households. We identify that access to electricity can reduce the subsidy for kerosene. Thus, the government needs to recycle the subsidy saving into promoting energy infrastructure. It also needs to determine standards for electricity access and to ensure the sustainability of energy access especially for small wattage needs. Such standards are necessary to ensure that there is no 'predatory' program. However, this can be implemented if all rural electrification programs are managed under one authority. Finally, central government and PLN need to promote open and transparent dialogue with local governments to ensure that all the parties have clear authority and responsibility in developing the electricity sector.

\section{REFERENCES}

AGECC. (2010). Energy for a sustainable future. The Secretary-General's Advisory Group on Energy and Climate Change. Summary report and recommendations. New York: United Nations.

Al Mohtad, I. (2006). 'Remote area power supply systems (RAPSS)'. Himalayan Small Hydropower Summit, (October I2-I3, 2006) Dehradun.

Badan Pusat Statistik/BPS (20I2). Manggarai Dalam Angka 20I2. Ruteng: BPS Kabupaten Manggarai.

IEA. (20I2). World energy outlook 20I2. Paris: OECD/ IEA International Energy Agency.

Kanagawa, M and T Nakata. (2008). 'Assessment of access to electricity and the socio-economic effects in rural areas of developing countries'. Energy policy, 36(6): 2016-2029.

McCawley, P. (I978). 'Rural electrification in Indonesia-is it time?' Bulletin of Indonesian economic studies, I4(2): 34-69.

Munasinghe, M. (I988). 'Rural electrification: international experience and policy in Indonesia'. Bulletin of Indonesian economic studies, 24(2): 87-105.

Peng, W and J Pan. (2006). 'Rural electrification in China: history and institution'. China and the world economy, I4(I): 7I-84.

PLN (Persero). (20I2). Statistik PLN. Jakarta: Perusahaan Listrik Negara.

Reiche, K, A Covarrubias and E Martinot. (2000). 'Expanding electricity access to remote areas: off-grid rural electrification in developing countries'. World power, 9: 52-6o.

UNDP (2005). Energizing the Millennium Development Goals: a guide to energy's role in reducing poverty. New York: UNDP. 